\title{
Osmanlı'da Milyoner Olmak; 18. Yüzyılın Başlarında Galata Zenginleri
}

\section{Özet}

\section{Mustafa Akbel*}

Osmanlı İmparatorluğu'nda servet sahiplerinin kim olduğu ve servetin nasıl oluştuğu konusu önemlidir. Bu konuda yapılacak çalışmalarda şer'iyye sicilleri içerisinde yer alan tereke kayıtları kayda değer bilgiler vermektedir. Bu makalenin amacı Osmanlı imparatorluğunun merkezinde önemli bir ticaret ve diplomatik merkez olan Galata kazası içerisinde servet sahiplerinin tereke kayıtları üzerine değerlendirme yapmaktır. Bu çalışmada 18 . yüzyılın başlarında servet sahibi günün milyoneri olan kişilere ait tereke kayıtları değerlendirilmiştir. Çalışma mikro olarak Galata'da zenginliğin kaynağını ortaya koymaya çalışmaktadır. Değerlendirme her ne kadar Galata kazasını ele alsa da makro olarak Osmanlı'da servetin oluşmasındaki etkenler hakkında fikir vermektedir. Servet sahipleri olarak ifade ettiğimiz bu kişiler günümüz milyarderi olarak ifade edilen bir milyon akçenin üzerinde varlığa sahip olan kimselerdir.

Anahtar Kelimler: Osmanlı, Galata, Tereke kayıtları, Milyoner, Zengin.

\section{Becoming A Millionaire in the Ottoman Empire; The Early $18^{\text {th }}$ Century Rich in Galata}

\section{Abstract}

It is important that who is the owner of wealth and how wealth is occured in the Ottoman Empire. Probate records in Shari'a courts are giving reasonable informaton in studies on this subject. The purpose of this article is to evaluate on probate records the fortunes of Galata accident which is a important center of commerce the diplomatic center of the Ottoman Empire. In this study, it is evaluated in day of the probate records of people who are millionaires, enormously wealthy in the early 18th century. This work seeks to reveal the source of wealth in Galata as a micro. Although the evaluations considers the Galata accident, it gives an idea about the factors in the Ottoman Empire that may take as macros in the occurrence of fortune. The people are the ones who have income over a million today billionaires expressed as reserve that we refer to as the owners of wealth.

Keywords: Ottoman, Galata, Legacy records, Millionaire, Rich.

\footnotetext{
Dr., Celal Bayar Üniversitesi, Fen-Edebiyat Fakültesi, Tarih Bölümü, akbel444@hotmail.com. (Makale Gönderim Tarihi: 19.11.2017; Makale Kabul Tarihi: 04.02.2018) (ORCID ID: 0000-0001-6903-1962).
}

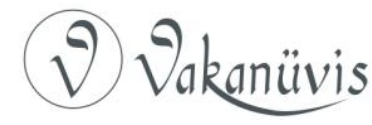




\section{Giriş}

Bilâd-ı selâse içinde yer alan Galata'da servetin oluşmasında içerisinde barındırdığı liman, topçu ocağı ve tarihi ticaret merkezinin kayda değer bir etkisi görülmektedir. Hem başkentin iaşesi hem de Anadolu'daki ticaret için önemli bir merkez konumunda olan Galata; Kasımpaşa, Tophane ve Beşiktaş gibi döneminde önemli sayılabilecek işlevleri olan merkezleri içerisinde barındırmaktaydı. Dahası bu merkezîlik Osmanlı ile sınırlı olmayıp, dünya ticaretinin de belirleyiciliğini kabullendiği önemli bir konuma hâizdi. ${ }^{1}$ Kaza aynı zamanda Müslim ve gayrimüslimlerin değişik etnik ve dini kökenden insanları barındıran; öteki, farklı, başka kavramları ile ifade edilebilecek unsurlardan oluşmaktaydı. Özellikle Galata sınırları dâhilinde bulunan Kasımpaşa Limanı zenginliğin temelini oluşturması açısından önemlidir. Kasımpaşa hem devlet tersanesinin merkezi hem de başkentin sivil deniz ticaretinin merkezi konumundaydı. Pek çok tüccar, kaptan ve devlet görevlisinin mukim olduğu önemli yerlerden biriydi. ${ }^{2}$

Osmanlı tarihi çalışmalarında önemli kaynaklardan biri olan Şer'iyye sicilleri üzerine pek çok çalışma yapılmıştır. Şer'iyye sicilleri içerisinde yer alan tereke kayıtları yerel tarih çalışmalarında önemli bir yer işgal etmektedir. Yapılan çalışmalar genel olarak alınan kayıtların istatistik değerlendirmelerine dayanmaktadır. ${ }^{3}$ Bunun dışında bürokrasiden yani askeri sınıftan ön plana çıkanların terekeleri üzerine çalışmalar yapılmıştır. Bu makalede ise Galata'ya ait 3490 tereke kaydından sadece dönemin milyonerlerine ait 1 milyon akçenin üzerinde olan

\footnotetext{
${ }^{1}$ Halil İnalcık, Ottoman Galata 1453-1553, Ottman History, İstanbul 1998, s.30; Eremya Çelebi Kömürciyan, XVII. Asırda İstanbul, Ter. H. D. Andreasyan, İstanbul 1988, s. 14-19; Kerim İlker Bulunur, Osmanlı Galatası (1453-1600), İstanbul 2014, s.83.

2 ilber Ortaylı, "Galata”, Türkiye Diyanet Vakfı Yayınları, C. 13, İstanbul, 1996, 300-305; Semavi Eyyice, "Galata”, Dünden Bugüne Istanbul Ansiklopedisi, Cilt 3. İstanbul, 1994, s. 348.

3 Ömer Lütfi Barkan, “Edirne Askeri Kassamına Ait Tereke Defterleri (1545-1659)" Belgeler III, S. 5-6, (1966), s.1-479; Said Öztürk, Askeri Kassama Ait On Yedinci Asır İstanbul Tereke Defterleri (Sosyo-Ekonomik Tahlil), İstanbul, 1995, s.10-70; Tülay Artan, "Terekeler Işığında 18. Yüzyıl Ortasında Eyüp'te Yaşam Tarzı ve Standartlarına Bir Bakış: Orta Halliliğin Aynası". Ed. Tülay Artan. 18. Yüzyıl Kadı Sicilleri Işığında Eyüp'te Sosyal Yaşam, Tarih Vakfı Yurt Yayınları, İstanbul 1998, s. 49-64.
}

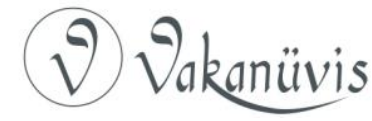


tereke kayıtları değerlendirmeye alınmıştır. ${ }^{4}$ Bir milyon akçe, incelenen dönemde 8 bin 333 kuruşa denk gelmektedir. ${ }^{5}$ Incelenen defterlerde sadece sekiz tereke kaydının 1 milyon akçenin üzerinde olduğu tespit edildi. ${ }^{6} \mathrm{Bu}$ durum istatistik olarak \% 0.22 gibi bir orana karşılık gelmektedir. Burada akla gelen soru neden 1 milyon akçenin üzerindeki kişileri incelemeye aldığımı sorusudur. Bu sorunun cevabı şöyle verilebilir; incelenen dönemde Osmanlının en üst rütbesinde bulunan kişilerin miras miktarlarının 1 milyonun üzerinde olduğu görülmektedir. ${ }^{7}$

Çalışma mikro olarak Galata'da zenginliğin kaynağını ortaya koymaya çalışmaktadır. Ancak değerlendirme her ne kadar Galata kazasını ele alsa da makro olarak Osmanlı'da zenginliğin oluşmasındaki etkenler hakkında fikir vermektedir. Tereke kayıtlarında değerlendirmeye alınan varlıklı kişiler muhtemelen kazanın zenginleri arasındaydı. Zengin olanların miraslarının deftere kaydedilme intimali yüksektir. Çünkü bu kişilerin servetlerinin bölüşülmesinde varisler arasında tartışma olma ihtimali bulunmaktadır. ${ }^{8}$

Bununla birlikte, tutulan tereke kayıtlarından bazı bilgilere ulaşmak mümkün olmamıştır. Örneğin, kişinin sahip olduğu eşyaları kendisinin mi aldığı; yoksa elinde bulunan eşyaların miras yolu ile mi geçtiği tam olarak belli değildir. Bunun yanı sıra, zenginlerden tüccar olanların kimler ile ticari ilişkide bulunduğu, alacak ve verecek ilişkisinin hangi ticaret ürünü ile ilgili olduğu bilgisi net değildir.

Çalışmada; Galata'da zenginliğin kaynağının ne olduğu, zenginlerin

\footnotetext{
${ }^{4}$ Galata Şer'iyye Sicsiclleri Defter Numaraları: 242, 243, 246, 247, 248, 249, 251, 252, 254, 255, 257, 258, 260, 262, 263, 268, 269, 271.

${ }^{5}$ Şevket Pamuk, "Kuruş", Türkiye Diyanet Vakfı Yayınları. C.16, İstanbul, 2002, s. 458459. Pamuk, Osmanlı-Türkiye iktisadî Tarihi 1500-1914, İstanbul 2005, s.171. Pamuk, istanbul ve Diğer Kentlerde 500 Yıllık Fiyatlar ve Ücretler 1469-1998. Ankara, 2000, s.10.

${ }^{6}$ Değerlendirilen Kayıtlar; G.Ş.S: 252/27A, 254/28D, 257/79A, 258/27C, 260/34A, 265/46F, 268/53B, 271/73A.

${ }^{7}$ Gülser Oğuz, Tereke Kaydından Hareketle Bir Osmanlı Vezirinin 18. Yüzyıl Başlarındaki Yaşam Tarzı:Amcazâde Hüseyin Paşa. Millî Folklor, S.88, (2010), s. 91-100.

${ }^{8}$ Suraiya Faroqhi, Osmanlı Dünyasında Üretmek, Pazarlamak, Yaşamak, Çev.Gül Çağalı Güven, Özgür Türesay, İstanbul, 2008, s.155.
}

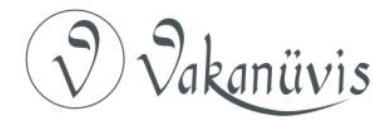


gelirlerini nerelerde değerlendirdikleri, genelde Osmanlı toplumunda gayrimenkule bağlanan gelirin, kazanın en zenginleri için de geçerli olup olmadığı gibi sorulara cevap verilmeye çalışılacaktır.

\section{I.Zenginlerin Yaşamı}

Osmanlı ekonomisinde 18. yüzyılın ilk yarısında, hemen hemen bütün sektörlerde bir genişleme meydana gelmiştir. Bu dönemde İstanbul, Halep, Bursa, Edirne gibi merkezlerde mevcut endüstri imalatı artmış, yeni faaliyet dalları ortaya çıkmıştır. Özellikle dokuma sanayi bu dönemin önemli bir pazarı olmuştur. ${ }^{9} \mathrm{Bu}$ dönemde ekonominin asıl aktörleri, önemli bir mal varlığına sahip olan seçkinler zümresiydi.

Tablo 1- Galata Milyonerleri

\begin{tabular}{|c|c|c|c|c|c|}
\hline Tereke Sahibi & $\begin{array}{l}\text { Tereke } \\
\text { miktarı }\end{array}$ & Borçları & Alacakları & Nakit & $\begin{array}{l}\text { Net kalan } \\
\text { Tereke }\end{array}$ \\
\hline $\begin{array}{l}\text { Abdullah Paşa } \\
\text { b. Abdullahtır. }\end{array}$ & $\begin{array}{l}3.371 .25 \\
4\end{array}$ & 286.320 & 186.000 & 20.000 & $\begin{array}{l}2.996 .97 \\
4\end{array}$ \\
\hline $\begin{array}{l}\text { Tersane-i Amire } \\
\text { Kethüdaların- } \\
\text { dan El-hac Mu- } \\
\text { sa Paşa b. } \\
\text { Mehmed }\end{array}$ & $\begin{array}{l}3.037 .03 \\
9\end{array}$ & 600.281 & $\begin{array}{l}1.200 .00 \\
0\end{array}$ & & $\begin{array}{l}2.352 .07 \\
4\end{array}$ \\
\hline $\begin{array}{l}\text { Kaptan Süley- } \\
\text { man Paşa b. } \\
\text { Mustafa b. } \\
\text { Abdurahmandır. }\end{array}$ & $\begin{array}{l}2.278 .70 \\
7\end{array}$ & 241.080 & & & $\begin{array}{l}1.830 .78 \\
2\end{array}$ \\
\hline
\end{tabular}

\footnotetext{
${ }^{9}$ Mehmet Genç, Osmanlı Imparatorluğunda Devlet ve Ekonomi, İstanbul, 2000, s. 99152.
} 


\begin{tabular}{|c|c|c|c|c|c|}
\hline $\begin{array}{l}\text { Mîr-zâde Mus- } \\
\text { tafa Kapudan b. } \\
\text { Hüseyin } \\
\text { Kapudan b. El- } \\
\text { hac Mustafa }\end{array}$ & $\begin{array}{l}1.711 .26 \\
3\end{array}$ & $\begin{array}{l}102992 \\
0\end{array}$ & 201.600 & & \\
\hline $\begin{array}{l}\text { Kalyon Kaptanı } \\
\text { olan Şerif Ibra- } \\
\text { him Kapudan b. } \\
\text { Mehmed }\end{array}$ & $\begin{array}{l}1.514 .38 \\
0\end{array}$ & 368.640 & & & \\
\hline Hristo v. Vasil & $\begin{array}{l}1.201 .56 \\
0\end{array}$ & & 486.000 & & $\begin{array}{l}1.155 .96 \\
0\end{array}$ \\
\hline $\begin{array}{l}\text { Ermeni Bezzaz } \\
\text { Karazos v. Kirko }\end{array}$ & $\begin{array}{l}1.020 .57 \\
5\end{array}$ & & & $\begin{array}{l}900.00 \\
0\end{array}$ & 969.155 \\
\hline $\begin{array}{l}\text { El-hac Yusuf b. } \\
\text { Ahmed }\end{array}$ & $\begin{array}{l}1.089 .09 \\
1\end{array}$ & & & & $\begin{array}{l}1.039 .87 \\
1\end{array}$ \\
\hline
\end{tabular}

Zenginlerin yaşamlarına ilişkin bilgilere; sadece miras taksimlerinden önce haklarında verilen kişisel bilgilerden ulaşılmaktadır. Bu bilgiler ışığında mikro bir bakış açısı ile Galata kazasında zenginliğin kaynağının ne olduğu ve müteşebbislerin kim olduğu bilgisine ulaşmaya çalışacağız. Bunun için öncelikli olarak seçkinler sınıfını tanıtmak gerekir. Bunlardan biri, Galata'ya bağlı Fındıklı Ali Çelebi Mahallesi'nde mukim olan Kaptan Süleyman Paşa b. Mustafa b. Abdurahman'dı. İsminin başına almış olduğu Kaptan ve Paşa unvanı devletin donanmasında görev yaptığını göstermektedir. Kaptan Süleyman Paşa, seyr-i sefer esnasında vefat etmiştir. Kaptan Süleyman Paşa'nın terekesi kethüdası olan Ali Ağa b. Ahmed tarafından satılmıştır. 
O, Süleyman Paşa'nın hayatta iken yaptığı vasiyet üzerine bunu gerçekleştirmiştir. Ticaret ile uğraşan ve varisi bulunmayan Süleyman Paşa'nın borcu, muhtemelen satılan eşyaların parası ile verilmiştir. ${ }^{10}$

Zenginlerimizden bir diğeri ise Balık Pazarı İskelesi'nde kalyon kaptanı olan Şerif İbrahim Kapudan b. Mehmed'dir. Şerif İbrahim'in Mirasçıları arasında eşi, üç kızı ve bir oğlu vardı. Yaptığı taşımacılık ve ticaret işleri nedeniyle çok sayıda alacak-verecek ilişkisi bulunmaktaydı. Kendisine borçlu olanlardan biri de, arkadaşı olan Galata zenginlerinden Kaptan Süleyman Paşa'ydı. ${ }^{11}$

Bir diğer Galata zengini, Azak Kalesi'nden Kasımpaşa Limanı'na mal veya envanteri getirmesi sırasında vefat eden Abdullah Paşa b. Abdullah'tır. Abdullah Azak kalesinden Sahberaş karyesinde misafirlikten dönerken vefat etmiştir. Vefat sebebi hakkında bilgi bulunmamaktadır. Abdullah Paşa'nın sahip olduğu 145 esir ve gayrimenkulleri arasında "Çektirme" diye ifade edilen bir gemi de yer almaktadır. Muhtemelen deniz taşımalığı yapan Abdullah Paşa aynı zamanda bir köle tüccarıydı. Terekesinde çeşitli alacaklarının ve nakit parası var olduğu bilgisi yer almaktadır. Mirasçıları arasında eşi ve bir erkek evladı bulunmaktadır. ${ }^{12}$

Galata zenginlerinden bir başkası, Kemankeş Mustafa Paşa Mahallesi sakinlerinden El-hac Yusuf b. Ahmed'dir. Yusuf'un kendisine kalan miras, servetinin büyük kısmını oluşturmaktadır. El-hac Yusuf'un ise bir mirasçısı yoktur. ${ }^{13}$ Zenginler arasında yer alan bir diğer isim, yine kaptan olan Tophane Meyidzade Mahallesi sakinlerinden Mîr-zâde Mustafa Kapudan b. Hüseyin Kapudan b. El-hac Mustafa'dır. İskenderiye'de vefat etmiştir. İskenderiye'ye giden Mustafa Kaptan aynı zamanda divan kesiresi veya kesesi görevini yürütmekteydi. Tüccar olduğu anlaşılan Mustafa Kaptan çok miktarda ticari eşyaya sahipti.

\footnotetext{
${ }^{10}$ G.Ş.S., 252/27B.

${ }^{11}$ G.Ş.S., 260/34A; Daha sonraki dönemde İstanbul deniz merkezli taşımacılık için bkz., Aygün, "XIX. Yüzyıl Başlarında İstanbul Merkezli Osmanlı Deniz Taşımacılı̆̆ı-Istanbul Centered Ottoman Sea Transport In The Early XIX. Century, Osmanlı Tarihi Araştırma ve Uygulama Merkezi Dergisi OTAM, S. 23, (2008), s. 53-84.

${ }^{12}$ G.Ş.Ş., 257/79A.

${ }^{13}$ G.Ş.S., 265/46F.
}

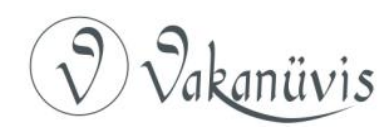


Mercimek ve kereste gibi ürünlerin ticaretini yapan kaptanın kendisine ait kalyon hissesi vardır. Üç kalyonda hissesi bulunan kaptanın satmış olduğu malların paralarından bir miktarı hâlâ verilmemiştir. İskenderiye ve İstanbul'da çeşitli ticari faaliyetleri olan Mustafa Kaptan'ın bunun sonucu olarak borçları-alacakları ticari ilişkisinin boyutunu göstermektedir. Osmanlı ticaretinin önemli aktörlerinden olan kaptanların oldukça yüksek meblağlarla ticareti canlandırdıkları söylenebilir. Mikro olarak bakıldığında dönemlerinde bölgenin ileri gelen zenginlerinin batı tarzında merkantilist bir yapıya büründüğü ortadadır. İskenderiye ve İstanbul'da çeşitli ticari faaliyetleri olan Mustafa Kaptan'ın bunun sonucu olarak borçları-alacakları ticari ilişkisinin boyutunu göstermektedir. ${ }^{14}$

Galata'da tespit ettiğimiz ikinci milyoner, Tersane-i Amire kethüdalarından El-hac Musa Paşa b. Mehmed'dir. Toplam tereke miktarı 3.037.039 akçe olan Musa Paşa'ya ait terekede çok sayıda değerli eşya vardır. Örneğin, sadece sahip olduğu bir kürkün fiyatı 45.000 akçedir. Onun bu kadar büyük bir gelire sahip olmasında devlet içerisindeki konumunun ve askeri sınıftan olmasının büyük bir etkisi vardır. Nitekim Tersane-i Amire'de kaptan paşanın emri altındaki tersane ricali ve tersane halkı başında bulunmaktaydı. Yani kaptan paşadan sonraki kişi tersahane kethüdası'ydı. Bu durum, Musa Paşa'nın zenginliğinin kaynağını ortaya koymaktadır. Paşa, çok sayıda tüfek ve kılıç gibi savaş aletlerine sahipti. Bunların dışında sahip olduğu değerli makbuz ve gayrimenkuller varlığının önemli bir kısmını oluşturmaktaydı. Mirasçıları arasında eşi ve bir çocuğu bulunmaktaydı. ${ }^{15}$

Bir diğer Galata zengini, Galata'ya bağlı Marmara Nahiyesi Paşa Limanı'ndan Hristo v. Vasil'dir. Muhtemelen ticaret ile uğraşan Hristo'nun ölümü ile alakalı herhangi bir bilgi verilmemiştir. Varisleri arasında eşi ve beş oğlu bulunmaktadır. Hristo, değirmen, gemi gibi çok sayıda gayrimenkule sahip olmanın yanında, pek çok kişinin borcunun olduğu bir toptancıydı. Bunların yanı sıra, değerli evrak ve tahıl ürünlerini muhafaza ettiği çok sayıda ambarı da mevcuttu. Hristo'ya

\footnotetext{
${ }^{14}$ G.Ş.S., 268/53B.

${ }^{15}$ G.Ş.S., $271 / 73$ A.
}

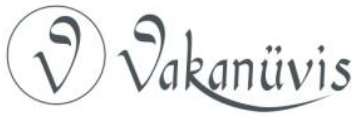


kimlerin borcu olduğunu ve bu borçların neye karşılık olduğunu bilemiyoruz. $^{16}$

Gayrimüslim zenginlerden bir başkası, Ermeni Bezzaz Karazos v. Kirkor'dur. Pek çok gayrimenkule sahip olan Bezzaz Karazos'un gelirinin çoğunluğunu bu sahip olduğu mülkler oluşturmaktadır. Bezzaz Karazos Sultan Beyazıd Mahallesi'nde vefat etmiştir. İsminin başına gelen ünvandan anlaşılacağı üzere Karazos, kumaş satan veya bezci olarak tabir edilen dönemin perakendecilerinden biriydi. Bu meslek muhtemelen aile mesleğiydi ve sahip olduğu mal varlığını bu meslek sayesinde elde etmişti. Mirasçıları arasında eşi ve üç çocuğu bulunmaktaydı. ${ }^{17}$

Değerlendirmeye alınan isimlerden altısının ticaret ile uğraştığı görülmektedir. Bunlardan dördü Müslüman'dı ve muhtemelen devlet kademelerinde görev yapan kişilerdi. Tüccarların ikisi ise gayrimüslimdi. Bunlar perakendecilik ve toptancılık yapmaktaydı. Diğer zenginlerden biri mirasçı, diğeri ise Tersane-i Amire kethüdasıydı.

Servet sahibi zenginlerin aile hayatlarına incelendiğinde ise, bunlardan altısının evli ve ikisinin bekâr olduğu görülmektedir. Evli olanların hepsi tek eşlidir. Çocuk sayıları ise değişmektedir. En çok çocuğa sahip olan isim, beş çocuk ile Hristo v. Vasil'dir. Hristo'dan sonra, dört çocuğu bulunan ibrahim Kaptan gelmektedir. Zenginlerden Bezzaz Karazos'un üç, Mustafa Kaptan'ın iki ve Kethüda Musa'nın bir çocuğu bulunmaktadır. Abdullah Paşa b. Abdullah'ın ise hiç çocuğu yoktur. Bu bilgilerden, çocuk sahibi olanların ortalama çocuk sayısının üç olduğu ve gayrimüslim zenginlerin daha çok çocuğa sahip olduğu anlaşılmaktadır. Eş sayısının ise, bu isimlerin mal varlıklarıyla herhangi bir bağlantısının olmadığı görülmektedir. Galata'nın kendine özgü yapısının bu seçkinler sınıfının oluşmasında etkili olduğu anlaşılmaktadır.

\section{Zenginlerin Servet Kaynakları}

${ }^{16}$ G.S.S.S., 254/28D.
${ }^{17}$ G.Ş.S., 258/27C.

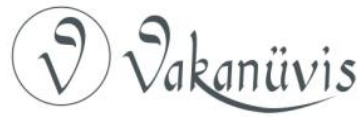


Seçkinler sınıfına mensup bu kişilerin zenginlik kaynaklarının ne olduğu meselesi önemli konulardan biridir. Zenginlerin sahip oldukları menkul ve gayrimenkullerin mirasa oranları ve çeşitleri, bu kişiler hakkında önemli bilgiler verebilmektedir. Bu isimler arasında en zengini, Azak Kalesi'nde vefat eden Abdullah Paşa b. Abdullah'tır. Toplamda 3.371.254 akçe serveti olan Abdullah Paşa'nın zenginliğinin önemli bir miktarını sahip olduğu gemide bulunan 145 esir oluşturmaktadır. Esirlerin toplam fiyatı 2.610 .000 akçedir. Bir esirin fiyatı ise 18.000 akçeye denk gelmektedir. Bu rakam, o dönemde Galata köle piyasasında ortalama bir kölenin fiyatıdır. Abdullah Paşa'ya ait bu köleler, muhtemelen Azak'ta tutulan savaş esirleridir. Devlet ile çeşitli ticari ilişkileri olduğu anlaşılan Abdullah Paşa'nın sahip olduğu gemi ise, zenginliğinin bir diğer kaynağıdır. Çektirme olarak ifade edilen gemisi ve içerisindeki eşyanın fiyatı 426.960 kuruştur. Servetinin diğer bir kısmını ise satmış olduğu ürünler veya vermiş olduğu borçlar oluşturmaktadır. Bunların toplam miktarı ise 132.600 akçedir. Servetinin diğer kısmını ise sahip olduğu kişisel eşyaları, elinde bulunan nakit parası ve ticari eşyaları meydana getirmektedir. ${ }^{18}$

Galata'da tespit ettiğimiz ikinci servet sahibi Tersane-i Amire kethüdalarından El-hac Musa Paşa b. Mehmed'dir. Toplam tereke miktarı 3.037.039 akçedir. Vefat ettiği zaman Tersane kethüdası olan Musa Paşa'nın gelirinin önemli bir kısmını elinde bulunan değerli makbuzlar oluşturmaktadır. Değerli makbuzların sahip olduğu servet içerisindeki miktarı 1.372.476 akçedir. Musa Paşa'ya ait menzillerin, bağ ve bahçenin miktarı ise 454.980 akçedir. ${ }^{19}$ Bunun dışında sahip olduğu kişisel ve değerli eşyalar ile köleler servetin diğer bir kısmını oluşturmaktadır. Musa Paşa'nın devlet içerisindeki konumu servetinin oluşmasında önemli bir etkiye sahiptir.

\footnotetext{
${ }^{18}$ G.Ş.S., 257/79A.

${ }^{19}$ G.Ş.S., 271/73A.
}

\section{(2) Vakanivisis}


Tablo 2- Sahip Oldukları Mülkler.

\begin{tabular}{|c|c|c|c|c|c|c|c|}
\hline Tereke Sahibi & $\begin{array}{l}\text { Ev- } \\
\text { ler }\end{array}$ & $\begin{array}{l}\text { Dükkân- } \\
\text { lar }\end{array}$ & $\begin{array}{l}\text { Bahçe } \\
\text { ve } \\
\text { arsa- } \\
\text { lar }\end{array}$ & $\begin{array}{l}\text { Köle- } \\
\text { er- } \\
\text { kek }\end{array}$ & $\begin{array}{l}\text { Köle } \\
\text { ka- } \\
\text { dın }\end{array}$ & $\begin{array}{l}\text { Değerli } \\
\text { mak- } \\
\text { buz }\end{array}$ & $\begin{array}{l}\text { Kal- } \\
\text { yon } \\
\text { veya } \\
\text { Gemi }\end{array}$ \\
\hline $\begin{array}{l}\text { Abdullah Paşa } \\
\text { b. Abdullah'tır. }\end{array}$ & & & & $\begin{array}{l}8 \\
\varnothing \\
-i \\
\text { Dे }\end{array}$ & & & 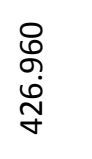 \\
\hline $\begin{array}{l}\text { Tersane-i Ami- } \\
\text { re Kethüdala- } \\
\text { rından El-hac } \\
\text { Musa Paşa b. } \\
\text { Mehmed }\end{array}$ & $\begin{array}{l}\underset{f}{\sim} \\
\infty \\
\stackrel{\sim}{f}\end{array}$ & & 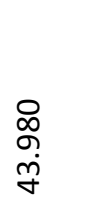 & $\begin{array}{l}8 \\
\varnothing \\
\infty\end{array}$ & 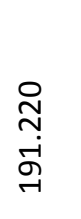 & $\begin{array}{l}\text { \& } \\
\dot{0} \\
\stackrel{+}{+} \\
\stackrel{-}{-}\end{array}$ & \\
\hline $\begin{array}{l}\text { Kaptan Süley- } \\
\text { man Paşa b. } \\
\text { Mustafa b. } \\
\text { Abdurahmandır } \\
\text {. }\end{array}$ & & & & & & & ষ্ণ \\
\hline $\begin{array}{l}\text { Mîr-zâde Mus- } \\
\text { tafa Kapudan b. } \\
\text { Hüseyin } \\
\text { Kapudan b. El- } \\
\text { hac Mustafa }\end{array}$ & $\begin{array}{l}\text { L } \\
\dot{-} \\
\stackrel{+}{\sim}\end{array}$ & & & & $\begin{array}{l}\text { o } \\
\text { ț } \\
\dot{f}\end{array}$ & $\begin{array}{l}8 \\
\stackrel{0}{1} \\
\dot{\phi} \\
\stackrel{2}{2}\end{array}$ & 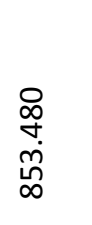 \\
\hline $\begin{array}{l}\text { Kalyon Kaptanı } \\
\text { olan Şerif İbra- } \\
\text { him Kapudan b. } \\
\text { Mehmed }\end{array}$ & & & & & & & $\begin{array}{l}8 \\
\stackrel{8}{0} \\
\stackrel{0}{n} \\
\text { ఢ }\end{array}$ \\
\hline Hristo v. Vasil & 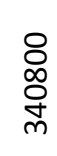 & $\begin{array}{l}\text { \& } \\
\& \\
\text { O }\end{array}$ & ষ & & & & $\begin{array}{l}8 \\
\stackrel{8}{i} \\
\stackrel{m}{r}\end{array}$ \\
\hline
\end{tabular}




\begin{tabular}{|l|l|l|l|l|l|l|l|}
\hline $\begin{array}{l}\text { Ermeni Bezzaz } \\
\text { Karazos v. Kirko }\end{array}$ & & $\begin{array}{c}\text { ○ } \\
\text { กे }\end{array}$ & & & & & \\
\hline $\begin{array}{l}\text { El-hac Yusuf b. } \\
\text { Ahmed'dir. } \\
\text { Ahmed }\end{array}$ & & & & & & & \\
\hline
\end{tabular}

Servet sahiplerinden bir diğeri, Fındıklı Ali Çelebi Mahallesi'nden Kaptan Süleyman Paşa b. Mustafa b. Abdurahman'dır. Kaptan Süleyman başkentin önemli tüccarlarından biriydi ve toplam tereke miktarı 2.278.707 akçeydi. Servetine ticaretini yaptığı atlas, hata-i, sof, çuka gibi kumaşlar ile bunlardan yapılan eşyalar kaynaklık etmekteydi. Bunun dışında tereke kaydında ona ait çok sayıda elmas, altın, gümüş eşya, tabanca ve tüfek gibi silahlar yer almaktaydı. Kaptanın genel olarak hangi bölge ile ticaret içerisinde olduğu bilgisini verecek net bir veri olmasa da alacak-verecek içerisinde olduğunu gösteren pek çok kayıt yer almaktadır. ${ }^{20}$

Bir diğer isim, yine kaptan tüccarlardan biri olan Mîr-zâde Mustafa Kaptan b. Hüseyin Kaptan b. El-hac Mustafa'dır. Mîr-zâde'nin tereke miktarı meslektaşı olan Süleyman Paşa'dan daha azdır. Toplam tereke miktarı 1.711.263 akçe olan Mîr-zâde'nin servetinin önemli bir kısmını gemi çeşitlerinden biri olan kalyonlarda bulunan hissesi oluşturmaktadır. Üç kalyonda bulunan toplam hisse miktarı 640.000 akçedir. Galata'nın önemli tüccarlarından olan Mîr-zâde'nin İskenderiye'de sattığı mercimeğin ve kerestenin ücret olarak karşılı̆̆ı 201.600 akçe iken, sahip olduğu gayrimenkullerin değeri ise $\mathbf{3 9 6 . 4 2 5}$ akçedir. Terekesinin diğer kısmını ise değerli evrakları, köleleri ve diğer eşyaları teşkil etmekteydi. Tüccar kaptanlardan biri olan Mîr-zâde Mustafa Kaptan'ın gelirinin kaynağını sahip olduğu kalyonlar, yapmış olduğu ticaret ve gayrimenkuller oluşturmaktadır. ${ }^{21}$

${ }^{20}$ G.Ş.S., 252/27B.
${ }^{21}$ G.Ş.S., 268/53B. 
Servet sahiplerinden bir diğeri de yine kaptan tüccarlardan biri olan Kalyon Kaptanı Şerif İbrahim Kapudan b. Mehmed'dir. Şerif İbrahim'in toplam mirası 1.514 .380 akçedir. Servetinin tamamını sahip olduğu kalyon hissesi oluşturmaktadır. Kalyonun tereke miktarı içerisindeki payı 1.500.000 akçedir. Sahip olduğu mirasın geriye kalan kısmını ise ibrahim'in kişisel eşyaları meydana getirmektedir. Galata'da özellikle ticaret ve gemi taşımacılığında Müslüman kaptanların önemli bir etkisinin olduğu görülmektedir. ${ }^{22} \mathrm{Bu}$ dönemde devlet içerisinde bulunan gayrimüslim tüccarlar genel olarak dış ticarette etkin iken iç ticarette Müslüman tüccarlar söz sahibi olduğu görüşü doğru değildir. Servet sahibi tüccarlar da buna örnek teşkil etmektedir. ${ }^{23}$ Halil İnalcık Osmanlı kentinde Müslüman tüccarların da büyük ölçüde ticaret içerisinde bulunduğunu belirtir. Ve yine Cemal Kafadar "Venedik'te Bir Ölüm" başlıklı bölümde Osmanlı'da Müslüman tüccarların daha ilk dönemlerden itibaren ticaretin içerisinde bulunduğu ve deniz aşırı ticarette de önemli bir yere geldikleri örnekleri ile anlatılmaktadır. Çalışmamızda servet sahiplerinden verilen örnekler de İnalcık ve Kafadar'ın bu iddialarını desteklemektedir. ${ }^{24}$

Galata'da servet sahiplerinden biri de tahıl toptancısı olan ve çok sayıda mahzen ve değirmeni bulunan Hristo v. Vasil'dir. Toplam tereke miktarı 1.201.560 akçedir. Hristo'nun mirasının önemli bir kısmını sahip olduğu gayrimenkuller ve vermiş olduğu tahıllara karşılık olan borçlar oluşturmaktadır. Hristo'nun alacaklarının miktarı 486.000 akçe iken gayrimenkullerinin miras içerisindeki payı ise 497.200 akçedir. Hristo'nun depo olarak kullandığı çok sayıda mahzeni de bulunmaktadır. Bunun dışında ticaretini yapmış olduğu malları

\footnotetext{
${ }^{22}$ G.Ş.S., 260/34A.

${ }^{23}$ Bruce, McGowan, "Ayanlar Çağı, 1699-1812", Ed.Halil İnalcık, Donald Quataert, Osmanlı Imparatorluğunun Ekonomik ve Sosyal Tarihi, Cilt 2, İstanbul, 2006, s. 847.

${ }^{24}$ Cemal Kafadar, Kim Var Imiş Biz Burada Yoğ iken, İstanbul, 2000, s. 73-122. Yine bunu destekler çalışmalar için bkz; Salih Özbaran, Ottoman Expansion Towards The Indian Ocean in The $16^{\text {th }}$ Century, İstanbul, 2009; Daniel Palzac, "International and Domestic Maritame Trade in The Ottoman Empire During The $18^{\text {th }}$ Century" International Journal of Middle East Studies, S. 24. s.197-202; Şerafettin Turan, "Venedik'te Türk Ticaret Merkezi", Belleten, S. XXXII, (1968), s. 251; W. Heyd, Yakın-Doğu Ticaret Tarihi, Çev. Enver Ziya Karal, Ankara, 2000, s.489-543; Necdet Ertuğ, Osmanlı Döneminde istanbul Deniz Ulaşımı ve Kayıkçılar, Ankara, 2001, s. 128-213.
}

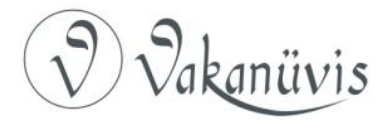


taşıyacak bir de gemiye sahiptir. Hristo'nun Galata'nın önemli bir toptancısı olduğu ve başkentin tahıl ticaretinin önemli isimlerinden biri olduğu anlaşılmaktadır. ${ }^{25}$

Hristo ne kadar tahıl perakendeciliğinde etkili ise servet sahiplerinden bir olan Ermeni Bezzaz Karazos v. Kirkor da kumaş ve bez perakendecisiydi. Karazos'un mirasının bir diğer kısmını kardeşinin elinde bulunan nakit paralar teşkil etmekteydi. Toplam tereke miktarı 1.020.575 akçe olan Karazos'un sahip olduğu nakit paranın miktarı 900.000 akçedir. Sahip olduğu servetin diğer kısmını ise sahip mülkiyetindeki menzil, ticari ve kişisel eşyalar oluşturmaktadır. İstanbul'un üretim merkezinden çok tüketim merkezi olması nedeniyle, kentin önde gelen tüccarları başkent halkının temel gıda maddelerini temin eden ve zaman zaman da stokçuluk yapan tüccarlar olmuştur. ${ }^{26}$

Servetleri tespit edilen varlıklı kişilerden devlet ve Tersane ile ilişkisi bulunmayan tek isim, Müslüman zengin El-hac Yusuf b. Ahmed'dir. Elhac Yusuf'un servetinin nereden geldiği ve ne gibi bir iş yaptığı ile alakalı net bir bilgi bulunmamakla birlikte balık pazarında dükkân sahibi olduğu görülmektedir. Gelirinin hepsi miras yolu ile kendisine aktarılmıştır. Muhtemelen ticaret ile uğraşan Yusuf, Galata'nın önemli müteşebbislerinden biri konumundadır. ${ }^{27}$

\section{Gayri Menkuller}

Yüzyıl başlarında incelediğimiz Galata zenginlerinin hepsi gayrimenkule sahip değildi. Nitekim Galata zenginleri içerisinde yer alan üç kişi taşımacılık ve ticarette etkili idi. Bunların kendilerine ait ya kalyonları vardı veya kalyon hissedarıydı. ${ }^{28}$ iki kalyonda hissesi bulunan

${ }^{25}$ G.S.S., 254/28D; İstanbul'un iaşesi hakkında bilgi için bkz., Lütfi Güçer Lütfi, "XVIII. Yüzyıl Ortalarında İstanbul'un İaşesi İçin Lüzumlu Hububatın Temini Meselesi", iktisat Fakültesi Mecmuası, C.11, (1952), s. 397-416; Faroqhi, Osmanlı'da Kentler ve Kentliler, İstanbul, 1994; Yaşar Yücel, Es'ar Defteri (1640 Tarihli) Ankara, 1992; Yücel Özkaya, 18. Yüzyılda Osmanlı Toplumu, İstanbul, 2008.

${ }^{26}$ McGowan, a.g.e., s.826.

${ }^{27}$ G.S.S., 265/46F.

${ }^{28}$ Gemi çeşitleri ve Denizcilik Tarihi ile ilgili bkz., İsmail Hakkı Uzunçarşılı, Osmanlı Devleti'nin Merkez ve Bahriye Teşkilatı, Ankara, 1988; Idris Bostan, Kürekli ve Yelkenli Osmanlı Gemileri, İstanbul, 2005; Palmira Brummet, Osmanlı Denizgücü, İstanbul, 2009.

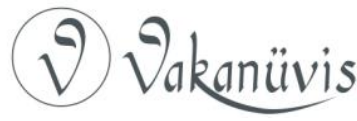


El-hac Mîr-zâde'nin toplam kalyon hissesi 640.000 akçeydi. ${ }^{29}$ Kalyon sahiplerinden Şerif İbrahim Kaptan'ın sahip olduğu kalyonun fiyatı 1.500 .000 akçe iken; ${ }^{30}$ Azak Kalesi'nden İstanbul'a taşımacılık yapan Abdullah Paşa'nın çektirme olarak tabir edilen gemisinin fiyatı ise 426.960 akçeydi. ${ }^{31}$ Gemi sahiplerinden bir diğeri ise tahıl toptancılığı yapan Hristo'ydu. Hristo'nun mallarının taşımasında kullandığı biri 96.000 akçe ve diğeri 36.000 akçe değerinde olan iki gemisi bulunmaktaydı. ${ }^{32}$

Servet sahipleri içerisinde dört kişi menzil sahibiydi. Menzil sahipleri içerisinde en çok menzile Tersane-i Amire kethüdası olan Musa Paşa sahipti. Musa Paşa'ya ait menzillerden sadece birinin fiyatı 300.000 akçe olup, menzillerinin toplam fiyatı 428.247 akçeydi. Musa Paşa'nın menziller dışında iki de bahçesi bulunmaktaydı. Ancak bahçeleri hakkında ayrıntılı bir bilgi bulunmamaktadır. Bahçelerinin toplam fiyatı 43980 akçeydi. ${ }^{33}$ Menzil sahibi bir diğer isim, gayrimüslim Hristo v. Vasil'di. Onun sahibi olduğu iki mülk menzilinin fiyatı, 348.000 akçeydi. Hristo aynı zamanda ticaretini yaptığı tahıın muhafazası için çok sayıda mahzene sahipti. Bu mahzenlerin fiyatı 3000 ile 6000 akçe arasında değişmekteydi. ${ }^{34}$ Bunun dışında bezzaz olan Ermeni Karazos'un 96000 akçe ve Kaptan Hüseyin Paşa'nın 194.364 akçe değerinde menzilleri bulunmaktaydı. ${ }^{35}$

Zenginler içerisinde Kaptan Süleyman Paşa ve el-Hac Yusuf herhangi bir gayrimenkule sahip değildi. Tereke miktarı olarak oldukça yüksek bir gelire sahip olan Kaptan Süleyman ve El-hac Yusuf'un paralarını daha çok ticarette değerlendirdiği anlaşılmaktadır. ${ }^{36}$

Buraya kadar verilen bilgiler değerlendirildiğinde, Galata'da değerlendirmeye alınan zenginlerin çok fazla bir mülke sahip olmadığı ve mülk sahibi olanların da oturdukları ev dışında paralarını

\footnotetext{
${ }^{29}$ G.Ş.S., 268/53B.

${ }^{30}$ G.Ş.S., 260/34A.

${ }^{31}$ G.Ş.S., 257/79A.

${ }^{32}$ G.Ş.S., 254/28D.

${ }^{33}$ G.Ş.S., $271 / 73$ A.

${ }^{34}$ G.Ş.S., 254/28D.

${ }^{35}$ G.Ş.S., 258/27C.

${ }^{36}$ G.Ş.S., 252/27A, 265/46F.
}

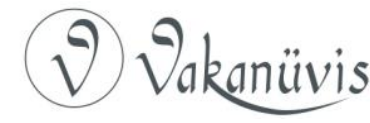


gayrimenkule yatırmadıkları görülmektedir. Özellikle deniz taşımacılığında etkin olanların gemi sahibi veya hissedar oldukları tespit edilmektedir.

\section{Alacakları ve Borçları}

Galata zenginleri borç ve alacak ilişkisi içerisinde bulunmuşlardır. Değerlendirmeye alınan servet sahiplerinden altısı borçlu veya alacaklı konumundadır. Sekiz tereke sahibinin toplam tereke miktarı 15.213.867 akçedir. Borçları ise 2.526.241 akçedir. Yani toplam borcun servet miktarına oranı \%16.60 denk gelmektedir. Toplam borçlarının ortalama miktarı böyle olsa da içlerinden özellikle Mustafa Kapudan b. El-hac Hüseyin Kapudan b. El-hac Mustafa'nın 1.029.920 akçe gibi yüksek bir oranda borcu bulunmaktadır. Toplam tereke miktarı 1.711 .263 akçe olan Mustafa Kaptan'ın borcunun miktarı terekesinin \%60,18'ni kapsamaktadır. Borç oranı oldukça yüksek olan Mustafa Kaptan'ın gelir ve gider dengesinde bazı aksaklıkların olma olasılığı yüksektir. Mustafa Kaptan'nın yüklü miktarda borcu bulunmakla birlikte, sattığı mallara karşılık olarak verilen değerli makbuzların toplam miktarı bir hayli yüksektir. Bu makbuzların toplam miktarı 346.560 akçe olup, bunlara satılan kalyon hisseleri de dahil değildir ${ }^{37}$ Yine Süleyman Kaptan'ın Müslim ve gayrimüslimlere de çeşitli borçları bulunmaktadır. Taşıma yaptığı Sakız ve Rodos adasından bazı kimselere borcu bulunmaktadır. Meslek grupları içerisinden sucu, yemişci, kasap, kürekci ve yelkenci gibi kişilere çeşitli miktarda borcu vardır. Süleyman Kaptan'ın mehir borcu ise 66.000 akçe ile zenginliğini gösterecek bir miktardadır. ${ }^{38}$ Borç miktarı zenginler arasında en az olan Abdullah Paşa b. Abdullah'ın devlet ile iş yaptığını gösteren önemli delillerden biri miri'ye olan borç miktarıdır. Borçlarının toplam miktarı 186.000 akçedir. Abdullah Paşa'nın da eşinin mehri 90.000 akçe ile oldukça yüksek bir orandır. ${ }^{39}$

Servet sahipleri arasında toptancılık yapan iki gayrimüslim Hristo v. Vasil ve Ermeni Karazos'un ise herhangi bir borcu bulunmamaktadır. Ticaret ile uğraşan bu kişilerin borçlarının olmaması dikkat çekicidir. Çünkü genelde tüccarlar mal alıp verirken çeşitli borçlanmalara

\footnotetext{
${ }^{37}$ G.S.S.S., $268 / 53 B$.

${ }^{38}$ G.S.Ş., 252/27A.

${ }^{39}$ G.S.Ş., 252/27A.
}

\section{(2) Valaniwis}


girmekteydi. Hiçbir borcu bulunmayan Hristo'nun buna karşılık, oldukça yüksek bir oranda alacağı bulunmaktaydı. Alacaklarının toplam miktarı 487.200 akçeydi. Hristo'ya kimlerin borcu olduğu belirtilmeden "ahalinin borcu" ismi altında çok miktarda alacağı bulunmaktaydı. Ahalinin borcu dışında Yorgo isimli bir gayrimüslimin 72.000 akçe borcu bulunmaktadır. ${ }^{40}$

Alacaklılar arasında en yüksek miktara sahip olan isim, Tersane-i Amire Kethüdası Musa Paşa'ydı. Musa Paşa'nın toplam alacak miktarı 1.200.000 akçeydi. Musa Paşa konumunun vermiş olduğu itibar ve aileden gelen bir zenginlik ile farklı miktarlarda borçlar vermiştir. Sahip olduğu kahveden iyi bir gelir elde ettiği, buradan 1.200 .000 akçe alacağının bulunmasından anlaşılmaktadır. ${ }^{41}$ Alacaklılardan bir diğeri ise Abdullah Paşa b. Abdullah'tır. Taşımacılık sektöründe önemli isimlerden biri olan Abdullah'ın, İsmail Paşa ve Mehmed Reis gibi isimlere borcu bulunmaktadır. ${ }^{42}$

Bu bilgilerden anlaşıldığına göre, genel olarak Galata'da taşımacılık, perakende ve ticaret ile uğraşan zenginlerin borç ve alacak ilişkilerinde zikredilen para miktarları da oldukça yüksektir. Genel olarak arazi ve taşınmaz mülklere çok fazla yatırım yapılmadığı görülmektedir. Devletin taşımacılık işlerini kısmen özel sektör üzerinden yürüttüğünü gösteren alacak-verecek ilişkisinin olduğu anlaşılmaktadır. ${ }^{43}$

\section{Köleler}

Zenginler arasında sadece ikisinin köleleri olduğu anlaşılmaktadır. Tersane-i Amire Kethüdası Musa Paşa'nın; aş̧̧ı cariye Şehbaz (36.000 akçe)[ aş̧ı cariye Şehbaz (36.000 akçe)], cariye Fatı (41.000 akçe), sağir gulam (8.800 akçe), cariye benam Asi (15.720 akçe), cariye Safiye (28.800 akçe), sağir cariye 6000 akçe, cariye Latife (31.100 akçe), cariye (19200 akçe) ve cariye Hanım (13.400 akçe) isminde cariye ve köleleri bulunmaktadır. ${ }^{44}$ Bunun dışında Azak-Galata arasında taşımacılık yapan

\footnotetext{
${ }^{40}$ G.S.Ş., 252/27A.

${ }^{41}$ G.Ş.S., 271/73A.

${ }^{42}$ G.S.S., 257/79A.

${ }^{43}$ Bedesten ve han ile ilgili bilgi için bkz., Robert Mantran, XVI ve XVII. Yüzyılda Istanbul'da Gündelik Hayat, İstanbul, 1991, s. 112-117; Kömürciyan, a.g.e., s. 14-19.

${ }^{44}$ G.Ş.S., 271/73A.
}

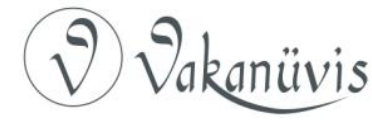


Abdullah Paşa b. Abdullah'a ait olup muhtemelen köle olarak satılacak 145 esirin toplam fiyatı 2.610 .000 akçedir. Bir esirin fiyatı 18.000 akçedir. Bu bilgilerden servet sahiplerinin çok fazla köle veya cariyeye sahip olmadıkları anlaşılmaktadır. Kölelerin özellikleri ile ilgili herhangi bir bilgi ise verilmemiştir. ${ }^{45}$

\section{Değerli Eşyalar ve Silahlar}

Servet sahiplerinin zenginliklerinin bir diğer göstergesi, değerli eşyalardı. Bu çalışmada ele alınan zenginlerden bir kısmının miras kayıtlarında herhangi bir değerli eşya kaydına rastlanmamaktadır. Biz bu başlık altında; sadece terekesinde değerli eşyalar bulunan zenginlerin ne gibi değerli eşyalara sahip oldukları ve miktarları hakkında bilgiler vermeye çalışacağız. Örneğin, muhallefat kayıtları içerisinde Kethüda Musa Paşa'nın tereke kaydında çok miktarda değerli eşya geçmektedir. Bu eşyalar ve değerleri şöyledir: İnci saat (3400 akçe), altın kemer tokası (3960 akçe), incili tarak kesesi (3800 akçe), yıldızı sim raht ma kemer raht (15000 akçe), sim garade (1800 akçe), sim kemer raht (12100 akçe), sim cebkun raht (7200 akçe), zümrüd küpe çift (17000 akçe), sağir kemer raht (11000 akçe) taraklı saat (1700 akçe), sim raht (4000 akçe, inci kuşak (29000 akçe), taşlı ekend:16000, simli eğer (3600 akçe), zümrüd taş (2000 akçe), atlas yüzük (9400 akçe), şikest yüzük (1200 akçe), sim maşrebe (1056 akçe), altın kuşak çift (17480), altın bilezik (12377 akçe), altın (2400 akçe), sim akar saat (2200 akçe), bozuk saat (2199 akçe) ve bunların dışında fiyatı (2001000 akçe) arasında değişen simli kuşaklar. ${ }^{46}$

Değerli eşyalara sahip bir diğer kişi ise Kaptan Süleyman Paşa b. Mustafa b. Abdullah'tır. Kaptan tüccarlardan olan Süleyman Paşa çok miktarda değerli eşyaya sahiptir. Bunlar arasında; sim şamdan (8560 akçe), çalar saat (15100 akçe), yine saat (1800 akçe), sim satır kezdahe (61249 akçe), askı zincir ve resim (8510 akçe), sim terkeş (9000 akçe), alem der sim (4945 akçe), çerkez raht (2400 akçe), çukadar raht (4000 akçe), sim divan rahtı (20100 akçe), sim garalar (13400 akçe), rusume der sim (8866 akçe), sim raht (14994 akçe), sim raht çift (19440 akçe), sim raht (21800 akçe), sağir kemer raht (11000 akçe), sim kelebdan ve

\footnotetext{
${ }^{45}$ G.Ş.S., 257/79A.

${ }^{46}$ G.Ş.S., 272/27B.
}

\section{(2) Vadenuivis}


buhardan (4320 akçe), sim keçesi (16000 akçe), taşlı eklend (16000 akçe) zümrüd taş (2000 akçe), sim akar saat (2200) ve pek çok sim hayvan rahtı bulunmaktadır. Bunların fiyatları 10000 akçe ile 37000 akçe arasında değişmektedir.

Değerli eşyalar arasında çok sayıda silah da bulunmaktadır. Özellikle Kaptan Süleyman Paşa'ya ait çok sayıda ve çeşitte silah bulunmaktadır. ${ }^{47}$

Bu silahların fiyatları çeşidine ve özelliklerine göre değişiklik göstermektedir. Bunlar; üç çakmaklı tüfek (1520 akçe), Cezayir tüfek (1000-3750 akçe), boru tüfek (2400-3600 akçe), çift çakmaklı tüfek (1200-3200 akçe), boylu tüfek (1200-2660 akçe), kebir tüfek (720-1000 akçe), tabanca tüfek çift (1800 akçe), simli tüfek (2000 akçe), çift çakmaklı tabanca (2350 akçe) tabanca ma kabur çift (3600 akçe) tabanca (720 akçe), Peştu tabancası çift (2400 akçe), istanbul tüfek (1200 akçe)'tir.

Silah dışındaki diğer değerli eşyalar arasında; sim topuz (18006750), simli bıçak (2000 akçe), sim garede1800, sim kılıç (1600-3600 akçe), yıldızlı üzengi (1650), sim garade ma topuz (4000-6000 akçe), destar 8000 akçe, altın bıçak (3100 akçe), bakır kılıç (490 akçe), sim garade (2424 akçe), sim satır hançer, sim satır kezdahe 61249, kebir mert ( 9600 akçe) ve mızrak ( 210 akçe) yer almaktadır. Bunlar ile alakalı ayrıntılı bilgi tabloda verilmiştir:

Tablo 3: Silah Çeşitleri ${ }^{48}$

\begin{tabular}{|l|l|l|l|}
\hline Silah İsmi & Fiyatı & Silah İsmi & Fiyatı \\
\hline Kebir mert & $1020-3000$ & Pala & 370 \\
\hline Simli tüfek & 2000 & Bakır kılıç & 490 \\
\hline Simli bıçak & 2000 & Sim topuz & 1800 \\
\hline
\end{tabular}

${ }^{47}$ G.S.S., 258/27C, 252/27B, 258/27C.

${ }^{48}$ Tablo 3 ve sonra gelen tablolarda zenginlerin sahip oldukları eşyaların çeşitleri ve muhtevası verilmiştir. Kimin neye sahip olduğu bilgisi üzerinde durulmamış, zenginlerin sahip oldukları eşyaların çeşitleri ve fiyatları belirtilmiştir.

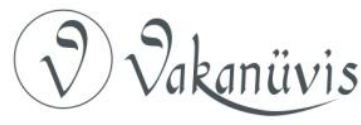




\begin{tabular}{|l|l|l|l|}
\hline Tabanca & 720 & Tabanca tüfek & 1800 \\
\hline Cezayir tüfek & $1000-1005$ & Pala bıçak & 1200 \\
\hline İstanbul tüfek & 1200 & Üç çakmaklı tüfek & 1520 \\
\hline Tüfek & $1000-1418$ & Boylu cezayir tüfek & 1400 \\
\hline Mert & 400 & Boru tüfek & $3600-7500$ \\
\hline Simli kılıc & $1600-3720$ & Çift çakmaklı tabanca & 2350 \\
\hline Sim garade & $1800-2424$ & Erslan puset & 205 \\
\hline Simli garade ma topuz & $4000-6000$ & Mızrak & 105 \\
\hline Peştu tabanca & 2400 & Sim pala & 2000 \\
\hline Kılıç sim & 1000 & & \\
\hline
\end{tabular}

\section{Ev Eşyaları ve Kişisel Eşyalar}

Galata zenginlerine ait çok sayıda ev eşyası ve kişisel malzeme de bulunmaktadır. Bunların ayrımı yapılırken özellikle ticari eşyalar ile karıştırmamaya dikkat edilmiştir. Bunun için, servet sahiplerinden sadece ev eşyaları yazıımış olanlar dikkate alınarak bir değerlendirme yapılmıştır. Bu eşyalar o kişinin konumu ve zenginliği hakkında bilgi vermektedir.

Ev eşyaları içerisinde; safir pişkir ve safir, yorgan, çentiyan, minder, yasdık, keçe, mak'ad, bohça, şilte, peşkir, çakşır, iskemle, şahta, kaplama, hasır, sakız seccadesi, cuka seccade, kaliçe, işleme havlu, örtü, çarşaf, seccade, döşek, kavuk, perde, sandık iskemle, duvar perdesi, işleme divan kesesi, asma saat, kilim, örtü keliçe, sandal boğça, şam kesmesi, taraklı saat, köhne kapama, iskimle örtüsü, atkılı iskemle, ayna, sözni makad, penbe şilte, kürek harabe gibi eşyalar bulunmaktaydı. Bunların sayısı ve niteliği hakkında daha detaylı bilgiler ekte verilecek tablolarda yer alacaktır. Kumaşların çeşidi ise; diba, cuka, tiftik, sandal, basma, hatayi ve safir gibi kumaşlardı. Ev eşyalarında genel olarak kadife kumaşın kullanıldığı görülmektedir.

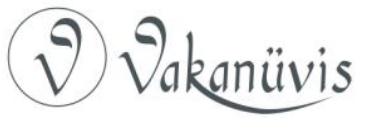


Tablo 4-Ev Eşyaları

\begin{tabular}{|c|c|c|c|c|c|}
\hline Eşya & Fiyatı & Eşya & Fiyatı & & \\
\hline Minder & $\begin{array}{l}690- \\
1790\end{array}$ & Seccade & 1000 & Yorgan & 600 \\
\hline Sal yasdık & $\begin{array}{l}1920- \\
3000\end{array}$ & Boğça & 120 & Peşkir iskemle & 1445 \\
\hline Balin yasdık & 250 & Mor yasdık & 120 & Silinek kaliçe & 329 \\
\hline Orta keçe & 1920 & $\begin{array}{l}\text { Cuka sec- } \\
\text { cade }\end{array}$ & 400 & $\begin{array}{l}\text { İşleme Divan } \\
\text { kesesi }\end{array}$ & 310 \\
\hline Cuka mak'ad zira-i & 600 & $\begin{array}{l}\text { Yeşil san- } \\
\text { dal yorgan }\end{array}$ & 480 & $\begin{array}{l}\text { Beyaz tımar } \\
\text { kesesi }\end{array}$ & 270 \\
\hline $\begin{array}{l}\text { Kırmızı cuk'a } \\
\text { mak'ad zira-i }\end{array}$ & 300 & $\begin{array}{l}\text { Sandal } \\
\text { boğça }\end{array}$ & 240 & $\begin{array}{l}\text { Beyaz kadife } \\
\text { hasır }\end{array}$ & 600 \\
\hline Yaşmak Mak'ad & 280 & $\begin{array}{l}\text { Diba } \\
\text { çentiyan }\end{array}$ & 480 & $\begin{array}{l}\text { Kırmızı kömür } \\
\text { sarısı }\end{array}$ & 600 \\
\hline Yemeni mak'ad & $\begin{array}{l}210- \\
940\end{array}$ & $\begin{array}{l}\text { Yıldızlı } \\
\text { üzengi }\end{array}$ & 1650 & Köhne kilim & 200 \\
\hline Çözme Yorgan & 400 & Simli eğer & 3600 & Orta kaliçe & 300 \\
\hline Boğça & 120 & $\begin{array}{l}\text { Taşlı sile- } \\
\text { cek }\end{array}$ & 4800 & Örtü kaliçe & 600 \\
\hline İskemle & 850 & $\begin{array}{l}\text { Yemeni } \\
\text { yasdık ma } \\
\text { alaf }\end{array}$ & 100 & Balta & 30 \\
\hline Timur iskemle & 90 & $\begin{array}{l}\text { Alaca } \\
\text { çarşab }\end{array}$ & 700 & $\begin{array}{l}\text { Fağfur kelebdan } \\
\text { ve buhardan }\end{array}$ & 6000 \\
\hline Kebir yorgan & 4200 & $\begin{array}{l}\text { Yemeni } \\
\text { yorgan ma } \\
\text { çarşab }\end{array}$ & 210 & Sandıklı iskemle & 1800 \\
\hline İncili tarak kesesi & 3800 & Atkılı is- & 90 & Beyaz seccade & 300 \\
\hline
\end{tabular}




\begin{tabular}{|c|c|c|c|c|c|}
\hline & & kemle & & & \\
\hline Müstağmel çift & 2040 & Mısır hasır & 200 & Sepet sandık & 1620 \\
\hline Hasır & 200 & $\begin{array}{l}\text { Eğer ma } \\
\text { tekelti }\end{array}$ & 600 & Pirinç kese & 37 \\
\hline Sakız seccadesi & 1500 & $\begin{array}{l}\text { Köhne } \\
\text { sandık }\end{array}$ & 40 & Çadırhane & 300 \\
\hline Cuka seccade & 1600 & $\begin{array}{l}\text { Halı secca- } \\
\text { de }\end{array}$ & 300 & Davlunbaz & 160 \\
\hline Kadife yasdık & 1050 & $\begin{array}{l}\text { Saka sec- } \\
\text { cade }\end{array}$ & 120 & Killar çadır & 1700 \\
\hline $\begin{array}{l}\text { Yemeni yorgan } \\
\text { çarşab }\end{array}$ & 700 & Alaca kilim & 210 & Kadife yasdık & 200 \\
\hline Çatma yasdık & 2500 & $\begin{array}{l}\text { Aba kapu } \\
\text { perde }\end{array}$ & 150 & $\begin{array}{l}\text { Kadife duvar } \\
\text { perdesi }\end{array}$ & 1230 \\
\hline Köhne kaliçe & 800 & $\begin{array}{l}\text { Kilimgar } \\
\text { yorgan }\end{array}$ & 270 & $\begin{array}{l}\text { Sandal duvar } \\
\text { perdesi }\end{array}$ & 329 \\
\hline Kapı perdesi & 60 & Kürde kilim & 1600 & $\begin{array}{l}\text { Yeşil mak'ad } \\
\text { kuşak }\end{array}$ & 1800 \\
\hline Beledi döşek & 300 & Sağir tahta & 100 & $\begin{array}{l}\text { Kırmızı duvar } \\
\text { perdesi }\end{array}$ & 705 \\
\hline Ocak perdesi & 480 & $\begin{array}{l}\text { İskemle } \\
\text { örtüsü }\end{array}$ & 120 & Duvar perdesi & 1000 \\
\hline Sandık iskemle & 630 & $\begin{array}{l}\text { Diba } \\
\text { yasdık }\end{array}$ & 720 & Pembe şilte & 905 \\
\hline Hatayi kilim & 4000 & Harar çift & 1200 & & \\
\hline Dülbent örtüsü & 260 & $\begin{array}{l}\text { Çuval ma } \\
\text { urgan }\end{array}$ & 35 & & \\
\hline $\begin{array}{l}\text { Cuka kumaş sec- } \\
\text { cade }\end{array}$ & 1200 & $\begin{array}{l}\text { Dülbent } \\
\text { örtüsü }\end{array}$ & 260 & & \\
\hline
\end{tabular}


Tereke sahiplerinin mutfak eşyaları ise şöyleydi: Mak'ad tabak, sini, leğen, ibrik, ocak güğüm, sahan, sahan tabak, tencere, kebir tas, hisar tabak, kazgan, Sakız fağfur, süzgü, kebir sini, şamdan, kahve makremesi, sim maşrebe, tas, cam tepsi, orta lenger, sim tas, kaşık, kehave tepsisi, fincan zarfı, fincan, maden maşrebe, kahve ibrik tepsi, fağfur kelebdan, nacurdan ve tencere kevgir.

Tablo 5: Mutfak ve Banyo eşyaları

\begin{tabular}{|l|l|l|l|l|l|}
\hline Eşya & $\begin{array}{l}\text { Fiyatı } \\
\text { Ortala }\end{array}$ & Eşya & Fiyatı & & \\
\hline Sağir tas & $180-680$ & Kevgir sahan & 120 & Kebir tencere & 420 \\
\hline Sini & $280-800$ & Cam tepsi & 45 & Kebir kahve ibrik & 120 \\
\hline $\begin{array}{l}\text { Leğen ma } \\
\text { ibrik }\end{array}$ & 300 & Sağir lenger & 300 & Timur miskal & 150 \\
\hline $\begin{array}{l}\text { Sağir abdest } \\
\text { leğen }\end{array}$ & 240 & Orta lenger & 120 & Tunç tabak & 240 \\
\hline Ibrik & 70 & Rikab & 384 & Ocak güğüm & 240 \\
\hline Ocak güğüm & 480 & Süzgü sahan & 150 & Sim raht & 4000 \\
\hline Sabun & $500-940$ & Orta sini & 900 & Sim maşrebe & 1056 \\
\hline Işleme havlu & 220 & Bıçak & 100 & İcili zarf kesesi & 1100 \\
\hline $\begin{array}{l}\text { Havlu } \\
\text { makreme }\end{array}$ & 210 & Taba & 751 & Kelabdan & 1440 \\
\hline $\begin{array}{l}\text { Sahan, leğen } \\
\text { tabak }\end{array}$ & 10200 & Kevgir keçe & 70 & Tunç tabak & 240 \\
\hline $\begin{array}{l}\text { Sahan tabak, } \\
\text { güğüm }\end{array}$ & 3360 & $\begin{array}{l}\text { Tencere ma } \\
\text { kapak }\end{array}$ & $\begin{array}{l}150- \\
300\end{array}$ & Ocak güğüm & 240 \\
\hline Sim ibrik & 1820 & Kahve tepsisi & 45 & Kebir tencere & 420 \\
\hline $\begin{array}{l}\text { Yıldızlı leğen } \\
\text { ibrik }\end{array}$ & 1000 & Kantar & 60 & Billur fağfur & 600 \\
\hline Tencere & 500 & Kapaklı hoşap & 120 & Fağfur tas & 150 \\
\hline
\end{tabular}




\begin{tabular}{|l|l|l|l|l|l|}
\hline & & tas & & & \\
\hline Cedid sini & 1226 & $\begin{array}{l}\text { Sağir sahan } \\
\text { kapak }\end{array}$ & 240 & Şeker tabağı & 50 \\
\hline Sahan & 2720 & Lenger kapak & 150 & Kara raht & 200 \\
\hline Hisar tabak & $30-150$ & Kadayıf tepsisi & 150 & Billur bardak & 100 \\
\hline Kebir tas & 180 & $\begin{array}{l}\text { Sahan şamdan } \\
\text { tas }\end{array}$ & 150 & $\begin{array}{l}\text { Billur tas ve } \\
\text { tabak }\end{array}$ & 120 \\
\hline Kazgan & 3600 & $\begin{array}{l}\text { Kebir fağfur } \\
\text { fincan }\end{array}$ & 24 & Matbah sandık & 120 \\
\hline $\begin{array}{l}\text { Hamam } \\
\text { gömlek }\end{array}$ & 360 & $\begin{array}{l}\text { Fağfur tabak } \\
\text { tas }\end{array}$ & 600 & $\begin{array}{l}\text { Nakış tabak } \\
\text { kapağı }\end{array}$ & 600 \\
\hline $\begin{array}{l}\text { Cedid mısır } \\
\text { makreme }\end{array}$ & 430 & $\begin{array}{l}\text { Cam kebir } \\
\text { fanus }\end{array}$ & 150 & Tuzluk & 600 \\
\hline Sakız fağfur & 3800 & Tunç mangal & 600 & Yağ & 120 \\
\hline Süzgü & 120 & Abdest leğen & 400 & Kapaklı tas & 120 \\
\hline Kebir sini & 1716 & Taba & 200 & Raht & 3000 \\
\hline Sim şamdan & 3564 & Musluk güğüm & 360 & Kömür raht & 1200 \\
\hline Sağir güğüm & 210 & $\begin{array}{l}\text { Kazanlı leğen } \\
\text { ibrik sablı tas }\end{array}$ & 215 & Havlu makreme & 120 \\
\hline
\end{tabular}

Servet sahiplerine (özellikle zengin tüccar kaptanlara) ait değerli eşyalar arasında bazı mesleki gereçler de bulunmaktaydı. Bunlar içerisinde; sancak, daralı bayrak, tur makarası, şerit makası, akrep saat, kalemdan, mısır makarası, bilek makarası, fener ve şerit yer almaktadır. Aşağıdaki tabloda daha ayrıntılı bilgiler bulunmaktadır.

Tablo 6: Mesleki Gereçler ve hububat

\begin{tabular}{|l|l|l|l|l|l|}
\hline Pirinç kile & 1250 & Sim tılsam & 133 & $\begin{array}{l}\text { Ambarda } \\
\text { hab }\end{array}$ & 1250 \\
\hline
\end{tabular}




\begin{tabular}{|l|l|l|l|l|l|}
\hline Sancak & 1100 & Tur makarısı & 2400 & $\begin{array}{l}\text { Pirinç } \\
\text { fiskal }\end{array}$ & 2400 \\
\hline Asma saat & 1200 & Hatayi rağ & 3800 & $\begin{array}{l}\text { Direk } \\
\text { şiltesi } \\
\text { örtüsü }\end{array}$ & 1320 \\
\hline Taraklı saat & 1700 & Şerit makası & 510 & $\begin{array}{l}\text { Direk } \\
\text { örtüsü }\end{array}$ & 470 \\
\hline Sim akar saat & 2200 & Mısır makarası & 1805 & $\begin{array}{l}\text { Kebir } \\
\text { fenar }\end{array}$ & 1400 \\
\hline Bozuk saat & 2199 & Çalar saat & 15100 & $\begin{array}{l}\text { Kalkan } \\
\text { saat }\end{array}$ & 3400 \\
\hline Akrep saat & 1200 & Defa saat & 1800 & $\begin{array}{l}\text { Sakız } \\
\text { makarası }\end{array}$ & 550 \\
\hline Taka tesbih & 1200 & Tur makarısı & 2400 & Çalar saat & $2400-3200$ \\
\hline Fenar & 120 & Sakız bayrağı & 12000 & $\begin{array}{l}\text { Bilek } \\
\text { makarası }\end{array}$ & 2400 \\
\hline
\end{tabular}

\section{Giysi Çeşitleri Değerli Kürkler ve Kumaşlar}

Servet sahiplerinin ya kendilerinin kullandığı ya da ticari eşya olarak satışını yaptıkları kumaşlar, giysiler ve kürkler de bulunmaktaydı. Yine bu çalışmada zenginler içerisinden sadece miras kayıtlarında bu tür eşyalar bulunanlar değerlendirmeye alınmıştır. Bunlardan özellikle Kaptan Süleyman Paşa çok sayıda değerli kumaş, elbise ve kürke sahiptir. Bu eşyaların fiyatları çeşitlerine göre değişiklik göstermektedir. Bunlar arasında; cuka, atlas, Sakız atlası, ipek, İstanbul kadifesi, diba, keçe, tiftik, Selanik keçe, hatayi ve Sakız hatayi gibi pek çok çeşit kumaş bulunmaktadır. Bu kumaşlar hem ham olarak bulunmakta ve hem de bunlardan yapılan çeşitli eşyalar yer almaktadır. Çok sayıda kürk sahibi de olan Süleyman Kaptan muhtemelen bunların ticaretini de yapmaktadır.

Süleyman Kaptan dışındaki zenginler de çok sayıda kürk, elbise ve döşemelik eşyaya sahiptir. Bunların genellikle cinsleri bellidir. 
Zenginlere ait kişisel eşyalar içerisinde çok fazla sayıda değerli eşya da (mesela; inci, altın ve sim kuşak) bulunmaktadır.

Tereke kayıtlarında yer alan giyim eşyaları şöyledir; ihram, gömlek, kemer, entari, düz gömlek, siyah poş, hamam gömlek, makrame, telli üslük, telli çekme, yağmurluk başık ve kise, sade, şal, dolama, kotani, hatayi rag, kırmızı cuka yelek, kaftan şalvar, kalpak ve cuka börk ortası. Tereke kayıtları içerisinde çok sayıda değerli kuşak ismi de geçmektedir: kuşak, şal kuşak, kemer şal kuşak, şatır kuşağı, sim kuşak ve çavşu kuşağı sim vb.

Giyim eşyaları arasında çok sayıda kürk çeşidi de yer almaktadır: samur kürk, sincap kürk, baş sincap kürk, kakum kürk, samur baş kürk, sof sincap kürk, nakışlı sof kürk, yeşil cuka kaplı kürk (43000 akçe), çözme sof kürk, sof kürk, yeşil cuka yağmurluk kürk (43000 akçe), sof kaplı samur kürk (30000 akçe), yeşil cuka kaplı kömür kürk (9000), yeşil cuka kaplı samur kürk (45000 akçe), kara saka kürk (1609 akçe), su samuru kürk (4200 akçe), cebe kürk (705 akçe), sof kakum kürk (2880 akçe), yeşil sof kürk (2000 akçe) zürafa kürk (2400 akçe), sansar kürk (6000 akçe) ve kunduz çakşır (350 akçe) fiyatındadır. ${ }^{49}$

\section{Tablo 7: Giyim Eşyaları}

\begin{tabular}{|l|l|l|l|l|l|l|l|}
\hline $\begin{array}{l}\text { Giyim Eşya- } \\
\text { Sı }\end{array}$ & Fyatı & $\begin{array}{l}\text { Giyim Eş- } \\
\text { yası }\end{array}$ & Fyatı & $\begin{array}{l}\text { Giyim Eşya- } \\
\text { Sı }\end{array}$ & Fyatı & $\begin{array}{l}\text { Giyim } \\
\text { Eşyası }\end{array}$ & Fyatı \\
\hline $\begin{array}{l}\text { Kırmızı } \\
\text { Ihram }\end{array}$ & 721 & Bez kuşak & 90 & $\begin{array}{l}\text { Cuka } \\
\text { nimtan }\end{array}$ & 600 & $\begin{array}{l}\text { Er kuşa- } \\
\text { ğı }\end{array}$ & 1260 \\
\hline $\begin{array}{l}\text { Beyaz ih- } \\
\text { ram }\end{array}$ & 720 & Şal kuşak & 660 & $\begin{array}{l}\text { Kadife } \\
\text { entari }\end{array}$ & 300 & $\begin{array}{l}\text { Aba } \\
\text { başlık }\end{array}$ & 65 \\
\hline Beyaz şilte & 215 & $\begin{array}{l}\text { Mantar } \\
\text { boğça }\end{array}$ & 60 & $\begin{array}{l}\text { Yemeni } \\
\text { peşkir }\end{array}$ & 60 & $\begin{array}{l}\text { Akça } \\
\text { tahtası } \\
\text { ma } \\
\text { şamdan }\end{array}$ & 130 \\
\hline Peşkir & 230 & Siyah kes- & 1370 & Köhne sof & 150 & Sakız & 660 \\
\hline
\end{tabular}

${ }^{49}$ G.Ş.S., $271 / 73$ A. 


\begin{tabular}{|c|c|c|c|c|c|c|c|}
\hline & & me & & çakşır & & peşkir & \\
\hline $\begin{array}{l}\text { Alaca ke- } \\
\text { mer }\end{array}$ & 1305 & $\begin{array}{l}\text { Kırmızı } \\
\text { cuka kesme }\end{array}$ & 2000 & $\begin{array}{l}\text { Köhne } \\
\text { nimtan }\end{array}$ & 480 & $\begin{array}{l}\text { Şam } \\
\text { kesmesi }\end{array}$ & 2000 \\
\hline Şahter & 1610 & $\begin{array}{l}\text { Sarı köhne } \\
\text { cebe }\end{array}$ & 300 & Cuka çakşır & 720 & Don & 120 \\
\hline Kablama & 60 & $\begin{array}{l}\text { Kunduz } \\
\text { çakşır }\end{array}$ & 350 & $\begin{array}{l}\text { Köhne } \\
\text { yelek }\end{array}$ & 60 & Fes & 100 \\
\hline Entari & 300 & $\begin{array}{l}\text { Alaca enta- } \\
\text { ri }\end{array}$ & 340 & $\begin{array}{l}\text { Köhne } \\
\text { zibun }\end{array}$ & 60 & Postal & 24 \\
\hline Düz gömlek & 3300 & $\begin{array}{l}\text { Beyaz } \\
\text { zibun }\end{array}$ & 90 & $\begin{array}{l}\text { Müstağmel } \\
\text { gömlek }\end{array}$ & 180 & $\begin{array}{l}\text { Pabuç } \\
\text { mest }\end{array}$ & 3 \\
\hline Örtü & 970 & Beyaz şal & 1600 & Kalpak & 200 & $\begin{array}{l}\text { Gayret } \\
\text { kuşağı }\end{array}$ & 2015 \\
\hline $\begin{array}{l}\text { Kemer şal } \\
\text { kuşak }\end{array}$ & 1800 & $\begin{array}{l}\text { Cuka } \\
\text { müstağmel } \\
\text { yağmurluk }\end{array}$ & 720 & Bez kuşak & 90 & $\begin{array}{l}\text { Kırmızı } \\
\text { kunduz } \\
\text { kaftan }\end{array}$ & 910 \\
\hline Şilte & 540 & Mavi ihram & 150 & Şal kuşak & 660 & $\begin{array}{l}\text { Atlas } \\
\text { kaftan } \\
\text { entari }\end{array}$ & 1500 \\
\hline Cuka kavuk & 40 & Yelek cuka & 100 & $\begin{array}{l}\text { Kırmızı } \\
\text { kuşak }\end{array}$ & 1800 & $\begin{array}{l}\text { Köhne } \\
\text { mavi } \\
\text { dolama }\end{array}$ & 320 \\
\hline Siyah poş & 300 & $\begin{array}{l}\text { Kırmızı } \\
\text { cezayir } \\
\text { ihram }\end{array}$ & 800 & $\begin{array}{l}\text { Kuşak ih- } \\
\text { ram }\end{array}$ & 200 & Peşkuni & 590 \\
\hline Mısır peşkir & 401 & $\begin{array}{l}\text { Beyaz } \\
\text { Cezaayir } \\
\text { ihram }\end{array}$ & 400 & Beyaz zibun & & $\begin{array}{l}\text { Yeşil } \\
\text { cuka } \\
\text { kavuk }\end{array}$ & 6400 \\
\hline Destar & 60 & Tiftik kuşak & 150 & $\begin{array}{l}\text { İşleme } \\
\text { peşkir }\end{array}$ & 1900 & $\begin{array}{l}\text { Cuka } \\
\text { börk }\end{array}$ & 1000 \\
\hline
\end{tabular}




\begin{tabular}{|l|l|l|l|l|l|l|l|}
\hline & & & & & & ortası & \\
\hline Telli üslük & 460 & $\begin{array}{l}\text { Beyaz en- } \\
\text { tari }\end{array}$ & 110 & Şatır kuşağı & 480 & $\begin{array}{l}\text { Sof } \\
\text { örtüsü }\end{array}$ & 70 \\
\hline Telli çekme & 415 & Alaca yelek & 40 & Kuşak & 3600 & $\begin{array}{l}\text { Sim } \\
\text { çavuş } \\
\text { kuşağı }\end{array}$ & 1300 \\
\hline $\begin{array}{l}\text { Çakşır } \\
\text { ri }\end{array}$ & 720 & Nakış fes & 120 & $\begin{array}{l}\text { Cedid des- } \\
\text { tar }\end{array}$ & 8000 & $\begin{array}{l}\text { Sakız } \\
\text { kuşağı }\end{array}$ & 105 \\
\hline $\begin{array}{l}\text { Sade } \\
\text { Alaca }\end{array}$ & 320 & $\begin{array}{l}\text { Mısır beyaz } \\
\text { çarşab }\end{array}$ & 300 & $\begin{array}{l}\text { Cuka yağ- } \\
\text { murluk } \\
\text { başlık ve } \\
\text { kise }\end{array}$ & 4800 & $\begin{array}{l}\text { Hatayi } \\
\text { şilte }\end{array}$ & 500 \\
\hline $\begin{array}{l}\text { Müstağmel } \\
\text { kadife } \\
\text { kaftan }\end{array}$ & 480 & $\begin{array}{l}\text { Kemer } \\
\text { kuşak }\end{array}$ & 600 & 1800 & Keçe fes & & \\
\hline
\end{tabular}

Tablo 8: Kürk Çeşitleri

\begin{tabular}{|l|l|l|l|l|l|l|l|}
\hline $\begin{array}{l}\text { Gömlekli } \\
\text { cuka kablı } \\
\text { Kürk }\end{array}$ & 2400 & $\begin{array}{l}\text { Yeşil cuka } \\
\text { kablı halka } \\
\text { kürk }\end{array}$ & 5400 & $\begin{array}{l}\text { Kırmızı } \\
\text { sof sincab } \\
\text { kürk }\end{array}$ & 1800 & $\begin{array}{l}\text { Yeşil sof } \\
\text { kürk }\end{array}$ & 2000 \\
\hline $\begin{array}{l}\text { Sincab } \\
\text { kürk }\end{array}$ & 800 & $\begin{array}{l}\text { Kırmızı sof } \\
\text { kürk }\end{array}$ & 1200 & $\begin{array}{l}\text { Tiftik cuka } \\
\text { kablı kürk }\end{array}$ & 3200 & $\begin{array}{l}\text { Cuka } \\
\text { kablı } \\
\text { cebe } \\
\text { kürk }\end{array}$ & 1620 \\
\hline $\begin{array}{l}\text { Baş } \\
\text { sincab } \\
\text { kürk }\end{array}$ & 1805 & $\begin{array}{l}\text { Cuka Sansar } \\
\text { behası kürk }\end{array}$ & 6000 & $\begin{array}{l}\text { Kırmızı } \\
\text { sof kakum } \\
\text { kürk }\end{array}$ & 3000 & $\begin{array}{l}\text { Cuka } \\
\text { kablı } \\
\text { Zürefa } \\
\text { kürk }\end{array}$ & 4000 \\
\hline $\begin{array}{l}\text { Kakum } \\
\text { kürk }\end{array}$ & 9000 & $\begin{array}{l}\text { Kara Saka } \\
\text { nimtan kürk }\end{array}$ & 1609 & $\begin{array}{l}\text { Sof sincab } \\
\text { kürk }\end{array}$ & 2200 & $\begin{array}{l}\text { Kara } \\
\text { saka }\end{array}$ & 2160 \\
\hline
\end{tabular}




\begin{tabular}{|l|l|l|l|l|l|l|l|}
\hline & & & & & $\begin{array}{l}\text { baran } \\
\text { kürk }\end{array}$ & \\
\hline $\begin{array}{l}\text { Yeşil } \\
\text { kakum } \\
\text { kürk }\end{array}$ & 860 & $\begin{array}{l}\text { Su samuru } \\
\text { kürk }\end{array}$ & 4200 & $\begin{array}{l}\text { Nakışlı sof } \\
\text { kürk }\end{array}$ & 1100 & $\begin{array}{l}\text { Kakum } \\
\text { kürk }\end{array}$ & 8000 \\
\hline $\begin{array}{l}\text { Kırmızı } \\
\text { cuka } \\
\text { köhne } \\
\text { samur } \\
\text { baş kürk }\end{array}$ & 2520 & $\begin{array}{l}\text { Kunduz } \\
\text { sincab kürk }\end{array}$ & 2800 & & & & \\
\hline
\end{tabular}

\section{Sonuç}

Osmanlıda kimlerin zengin olduğu ve bu zenginliğin kaynağının nereden geldiği önemli konulardan biridir. Bu çalışmada 18.yüzyılın başlarında İstanbul'un üç büyük kazasından biri olan Galata'da zengin kabul edebileceğimiz kişilere ait tereke kayıtları değerlendirilmiştir. Tereke kayıtlarının değerlendirilmesi sonucunda sekiz kişinin sahip olduğu mirasın bir milyon akçenin üzerinde olduğu tespit edilmiştir. Zenginlerden altısı Müslüman iken, ikisi ise gayrimüslimdir. Müslümanların zenginlik kaynağı devlet görevinde bulunmaları ve yapmış oldukları ticarettir. Gayrimüslimlerin zenginlik kaynağı ise toptancılık ve ticaret yapmalarının sonucudur.

Yapılan değerlendirmede ticaretin önemli aktörlerinin kaptan olduğu ve iç ticarette etkin oldukları anlaşılmaktadır. Özellikle kaptanların zengin olmasında, Kasımpaşa Limanı́nın önemli bir etkisinin olduğu anlaşılmaktadır. Değerlendirmeye alınan tüm isimlerden altısının ticaret ile uğraştığı görülmektedir. Bunlardan dördü muhtemelen devlet içerisinde görev yapan Müslüman kişilerdi. Tüccarların ikisi ise gayrimüslimdi. Bunlar perakendecilik ve toptancllık yapmaktaydı. Diğer Müslüman zenginlerden biri mirasçı, diğeri ise Tersane-i Amire Kethüdası'ydı.

Osmanlıda Müslüman tüccarlar daha ilk dönemlerden itibaren ticaretin içerisinde bulunmuş ve deniz aşırı ticarette de önemli bir yere gelmişlerdir. Galata'da taşımacılık, perakende ve ticaret ile uğraşan zenginlerin borç ve alacak ilişkilerinde zikredilen para miktarları da

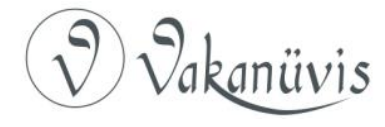


oldukça yüksektir. Devletin taşımacılık işlerini kısmen özel sektör üzerinden yürüttüğünü gösteren alacak-verecek ilişkisinin de olduğu anlaşılmaktadır. Özellikle deniz taşımacılığında etkin olanların gemi sahibi veya hissedar oldukları tespit edilmiştir. Genel olarak arazi ve taşınmaz mülklere çok fazla yatırım yapılmadığı görülmektedir. Servet sahipleri çok fazla köle veya cariyeye sahip olmamışlardır. Servet sahiplerinin ya kendilerinin kullandığı ya da ticari eşya olarak satışını yaptıkları kumaşlar, giysiler ve kürkler de bulunmaktaydı. Bunun dışında mesleki araç-gereç ve çok sayıda silah çeşidine sahip olmuşlardır.

\section{KAYNAKÇA}

Galata Şer'iye Sicilleri. 242.

Galata Şer'iye Sicilleri. 243.

Galata Şer'iye Sicilleri. 246.

Galata Şer'iye Sicilleri. 247.

Galata Şer'iye Sicilleri. 248.

Galata Şer'iye Sicilleri. 249.

Galata Şer'iye Sicilleri. 251.

Galata Şer'iye Sicilleri. 252.

Galata Şer'iye Sicilleri. 254.

Galata Şer'iye Sicilleri. 255.

Galata Şer'iye Sicilleri. 257.

Galata Şer'iye Sicilleri. 258.

Galata Şer'iye Sicilleri. 260.

Galata Şer'iye Sicilleri. 262.

Galata Şer'iye Sicilleri. 263.

Galata Şer'iye Sicilleri. 268.

Galata Şer'iye Sicilleri. 269.

Galata Şer'iye Sicilleri. 271.

Artan, Tülay, “Terekeler Işığında 18. Yüzyıl Ortasında Eyüp'te Yaşam Tarzı ve Standartlarına Bir Bakış: Orta Halliliğin Aynası", Ed. Tülay Artan, 18. Yüzyıl Kadı Sicilleri Işığında Eyüp'te Sosyal Yaşam, İstanbul1998, s.49-64.

Aygün, Necmettin, "XIX. Yüzyıl Başlarında İstanbul Merkezli Osmanlı Deniz Taşımacilığ-Istanbul Centered Ottoman Sea Transport In The Early XIX. Century, Osmanlı Tarihi Araştırma ve Uygulama Merkezi Dergisi OTAM, S.23, (2008), s. 53-84.

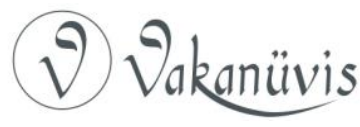


Barkan, Ömer Lütfi, “Edirne Askeri Kassamına Ait Tereke Defterleri (15451659)", Belgeler, S.III. 5-6, (1966), s.1-479.

Bostan, İdris, "Gemi", Türkiye Diyanet Vakfı Islam Ansiklopedisi, C. 14, (1996), s.8-15.

_Beylikten Imparatorluğa Osmanlı Denizciliği, İstanbul 2006.

_Osmanlı Bahriye Teşkilatı 17.Yüzyılda Tersane-i Amire, Ankara 2003.

_Kürekli ve Yelkenli Osmanlı Gemileri, İstanbul 2005.

Brummet, Palmira, Osmanlı Denizgücü, İstanbul 2009.

Bulunur, Kerim IIlker, Osmanlı Galatası (1453-1600), İstanbul 2014.

Çadırcı, Musa. "Hüseyin Avni Paşa'nin Terekesi”, Belgeler, S. 15. 145-164.

Demirel Ö.- Gürbüz A.-Tuş M., "Osmanlılarda Ailenin Demografik Yapısı”, Sosyo-Kültürel Değişme Sürecinde Türk Ailesi I, (1992) s.97-161.

Ertuğ, Nejdet, Osmanlı Döneminde Istanbul Deniz Ulaşımı ve Kayıkçılar, Ankara 2001.

Eyyice, Semavi, "Galata". Dünden Bugüne Istanbul Ansiklopedisi. Cilt 3, İstanbul 1994.

Faroqhi, Suraiya, Osmanlı Dünyasında Üretmek, Pazarlamak, Yaşamak, Çev. Gül Çağalı Güven, Özgür Türesay, İstanbul 2008.

_Osmanlı'da Kentler ve Kentliler, İstanbul1994.

Genç, Mehmet, Osmanlı Imparatorluğunda Devlet ve Ekonomi, İstanbul 2000.

Güçer, Lütfi, “XVIII. Yüzyıl Ortalarında İstanbul'un İaşesi İçin Lüzumlu Hububatın Temini Meselesi", iktisat Fakültesi Mecmuası, C.11, (1952), s. 397416.

Heyd, W., Yakın-Doğu Ticaret Tarihi, Çev. Enver Ziya Karal, Ankara 2000.

İnalcık, Halil, "XV. Asır Türkiye Iktisadi ve İçtimai Tarihi Kaynakları", iü iktisat Fakültesi Mecmuası. S. 15/1-4, s. 51-73;

_Ottoman Galata 1453-1553, Ottoman History, İstanbul 1998.

_Osmanlı Imparatorluğunun Sosyo-Ekonomik Tarihi, C.1, İstanbul 2009.

Kafadar, Cemal, Kim Var Imiş Biz Burada Yoğ Iken, İstanbul 2000.

Karpat, Kemal, Osmanlı'da Değişim, Modernleşme ve Uluslaşma, Çev. D. Özdemir, Ankara 2006.

Kömürciyan, Eremya Çelebi, XVII. Asırda Istanbul (Ter. H. D. Andreasyan), İstanbul 1988.

Mantran, Robert, XVI ve XVII. Yüzyılda İstanbul'da Gündelik Hayat, İstanbul 1991.

McGowan, Bruce, “Ayanlar Çağı, 1699-1812", Ed.Halil İnalcık, Donald Quataert, Osmanlı Imparatorluğunun Ekonomik ve Sosyal Tarihi, C. 2, İstanbul 2006.

Ortaylı, İlber, “Galata”, Türkiye Diyanet Vakfı Yayınları, C. 13, (1996), s 300 305.

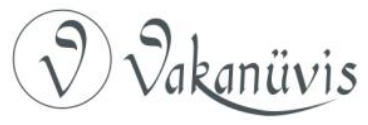


Oğuz, Gülser, Tereke Kaydından Hareketle Bir Osmanlı Vezirinin 18. Yüzyıl Başlarındaki Yaşam Tarzı: Amcazâde Hüseyin Paşa, Millî Folklor, S. 88, (2010), s. 91-100.

Özbaran, Salih, Ottoman Expansion Towards The Indian Ocean in The $16^{\text {th }}$ Century, İstanbul 2009.

Özdemir, Rıfat, "Kırşehir'de Ailenin Sosyo-Ekonomik Yapısı (1880-1906)", Osmanlı Araştırmaları, S. IX. (1989), s.101-157.

Özkaya, Yücel, 18. Yüzyılda Osmanlı Toplumu, İstanbul 2008.

Öztürk, Said, Askeri Kassama Ait On Yedinci Asır Istanbul Tereke Defterleri (Sosyo-Ekonomik Tahlil), İstanbul 1995.

Palzac, Daniel, "International and Domestic Maritame Trade in The Ottoman Empire During The $18^{\text {th }}$ Century" International Journal of Middle East Studies, S.24, (1992), s.197-202.

Pamuk, Şevket, "Kuruş" Türkiye Diyanet Vakfı Yayınları, C. 16, (2002), s.458-459.

Pamuk, Osmanlı-Türkiye Iktisadî Tarihi 1500-1914, İstanbul 2005.

Pamuk, İstanbul ve Diğer Kentlerde 500 Yılık Fiyatlar ve Ücretler 14691998, Ankara 2000.

Turan, Şerafettin, "Venedik'te Türk Ticaret Merkezi", Belleten, S. XXXII, (1968), s.251.

Uzunçarşılı, İsmail Hakkı, Osmanlı Devleti'nin Merkez ve Bahriye Teşkilatı, Ankara1988.

Yücel, Yaşar, Es'ar Defteri (1640 Tarihli), Ankara 1992. 